\title{
A KÖR NÉGYSZÖGESÍTÉSE: BUDAPEST LEHETŐSÉGEI A KELET-KÖZÉP-EURÓPAI VASÚTI VÁROSLÁTOGATÓ TURIZMUS ESETÉBEN
}

\author{
${ }^{1}$ Molnár Balázs $-{ }^{2}$ Lévai Zsolt \\ ${ }^{1}$ menetrendi szakértő, MÁV-START Zrt.; molnar.balazs@mav-start.hu \\ ${ }^{2}$ szenior kutató, KTI Közlekedéstudományi Intézet Nonprofit Kft.; PhD-hallgató, NKE HHK \\ Katonai Müszaki Doktori Iskola; levai.zsolt@kti.hu
}

DOI: 10.15170/TVT.2021.06.03.02.

\begin{abstract}
Absztrakt
A 2019 végén elindult koronavírus világjárvány jelentős mértékben átrendezte világunkat és értékrendünket. A védekezés miatti bezártságból kiszabadulva, az utazások engedélyezésével várható, hogy a turisztikai iparág mindent megtesz, hogy a korábbi utazási volumen visszaálljon és folytatódjon az idegenforgalom fellendülése. Eközben folyamatos a törekvés a kormányzati szereplők részéröl arra, hogy a fenntarthatóság irányába mozduljon el a közlekedési módok megoszlása. Ezek alapján cikkünk a vasúti közlekedés, mint környezetbarát utazási mód, és a turizmus viszonyát vizsgálja a közép-európai térségben. Az európai turisztikai piac egy jelentős hányadát teszik ki a térség szempontjából harmadik országnak tekinthető kiindulási helyről érkező városlátogató turisták. Sokan repülővel érkeznek Közép-Európába, majd a városközi közlekedésük egyik módja pedig a vasút igénybevétele. Tanulmányunk az eddig jól fejlődő közép-európai vasúti rendszerre alapozva mutat be új vasúti járattervezési lehetőségeket, ezáltal a vasút versenyképességének növelését célzó javaslatokat.
\end{abstract}

Kulcsszavak: járattervezés; városlátogató turizmus; vasúti turizmus; versenyképesség

\begin{abstract}
The coronavirus pandemic that started at the end of 2019 has significantly reshaped our world and our values. With travel being allowed to resume, the tourism industry is expected to do its utmost to restore previous travel volumes and continue the tourism boom, free from the protection lockdown. Meantime, there is a continuing push by government actors to shift the modal split towards sustainability. Connected to this background, this article examines the relationship between rail as an environmentally friendly mode of travel and tourism in the Central European region. A significant share of the European tourism market is made up of tourists visiting the region from third countries. Many people arrive in Central Europe by air, and then use rail as a mode of inter-city transport. Our study presents new options for rail route designing based on the well-developed Central European rail system, and thus proposals to increase the competitiveness of rail.
\end{abstract}

Keywords: product designing; city tourism; rail tourism; competitiveness 


\section{Bevezetés}

A címben megfogalmazott matematikai probléma, egy kör területével azonos területü négyzet szerkesztése, nem oldható meg az euklideszi geometria módszereivel, ugyanis $\pi$ értéke nem határozható meg teljesen pontosan körzővel és vonalzóval. Cikkünk címének eleje nem csak egy matematikai probléma, hanem egy, az 1920-as évek elején játszódó orosz színpadi mü címe is. Valentyin Katajev vígjátékában ${ }^{1}$ a sok félreértés utáni katarzisban a szereplők végül egymásra találnak és a szerelem ereje győzedelmeskedik. És hogy kapcsolhatók mindezek a kelet-közép-európai vasúti városlátogató körutazásokhoz? Reményeink szerint cikkünk végére kiderül.

A közelmúlt eseményei - bátran kimondható - alapjaiban változtatták vagy inkább változtatják meg a világ müködését - hiszen a folyamat még nem zárult le. Igaz ez a vasúti közlekedésre éppúgy, mint a turisztikai szolgáltatások piacára. Az egyik várható felfutási modell szerint a járvány lecsengése utáni újranyitás lökésszerü hatást indukálhat a turizmusnál, mert pótolva a lezárás alatt elhalasztott utazásokat (CSAPÓ-TÖRÖCSIK 2020), turisták tömege indulhat meg a bejáratott, jól ismert célpontok felé. A kiépített infrastruktúrák is igénylik a felhasználókat. Ezért feltételezzük, hogy a turizmust kiszolgáló közlekedési rendszert is jelentős hatás éri. Ez a hatás a közlekedés minden alágazatát eléri, így a vasúti szektort is. Kutatási hipotézisünk szerint a járvány után újrainduló utazások esetén Budapest és Magyarország jelentősége megnőhet, amennyiben a közép-kelet-európai turizmus egyik központjává fejlödik. Ez elősegíthető, ha a térségi turisztikai vasúti utazások kiindulópontja Budapest lesz. A KözépEurópába a tengeren túlról érkező turisták száma a járvány előtti előrejelzések szerint növekvő (1. táblázat). Ez megalapozhatja hipotézisünk helytállóságát.

1. táblázat. A föbb tengerentúli piacok kiutazó turizmusa (előrejelzés).

\begin{tabular}{|c|c|c|c|c|c|c|c|}
\hline Küldőpiac & $\begin{array}{c}\text { Kiutazó } \\
\text { turisták } \\
\text { száma } \\
\text { (ezer fö) }\end{array}$ & $\begin{array}{l}\text { Long haul } \\
\text { (tengeren } \\
\text { túli) úti } \\
\text { célok } \\
\text { részesedése }\end{array}$ & $\begin{array}{c}\text { Európa } \\
\text { részesedése a } \\
\text { long haul } \\
\text { turizmusból }^{* * *}\end{array}$ & $\begin{array}{l}\text { A KKE } \\
\text { régióba } \\
\text { érkező } \\
\text { turisták } \\
\text { száma } \\
\text { (ezer fő) }\end{array}$ & $\begin{array}{l}\text { A KKE }{ }^{*} \text { régió } \\
\text { részesedése } \\
\text { az európai } \\
\text { beutazások- } \\
\text { ból }\end{array}$ & $\begin{array}{c}\text { Az } \\
\text { Európába } \\
\text { irányuló } \\
\text { utazások } \\
\text { számának } \\
\text { változása }\end{array}$ & $\begin{array}{c}\text { A KKE } \\
\text { régióba } \\
\text { irányuló } \\
\text { utazások } \\
\text { számának } \\
\text { változása }\end{array}$ \\
\hline & \multicolumn{5}{|c|}{2016} & \multicolumn{2}{|c|}{ 2016-2021 } \\
\hline Argentína & 10608 & $29,6 \%$ & $38,8 \%$ & 136 & $11,2 \%$ & $+4,3 \%$ & $+38,0 \%$ \\
\hline Ausztrália & 16587 & $96,0 \%$ & $32,9 \%$ & 492 & $9,4 \%$ & $+15,2 \%$ & $+18,8 \%$ \\
\hline Brazília & 8187 & $71,4 \%$ & $48,6 \%$ & 257 & $9,0 \%$ & $+10,0 \%$ & $+21,5 \%$ \\
\hline $\mathrm{EAE}^{* *}$ & 3398 & $47,2 \%$ & $59,6 \%$ & 52 & $5,4 \%$ & $+9,4 \%$ & $+42,6 \%$ \\
\hline India & 15933 & $95,9 \%$ & $15,5 \%$ & 829 & $35,0 \%$ & $+52,3 \%$ & $+52,3 \%$ \\
\hline Japán & 22463 & $65,8 \%$ & $29,9 \%$ & 662 & $15,0 \%$ & $+34,0 \%$ & $+20,2 \%$ \\
\hline Kanada & 33145 & $38,5 \%$ & $38,7 \%$ & 335 & $6,8 \%$ & $+14,4 \%$ & $-15,5 \%$ \\
\hline Kína & 86036 & $45,6 \%$ & $26,5 \%$ & 3932 & $37,8 \%$ & $+62,8 \%$ & $+45,3 \%$ \\
\hline Mexikó & 21771 & $13,1 \%$ & $51,2 \%$ & 165 & $11,3 \%$ & $+21,8 \%$ & $+14,8 \%$ \\
\hline Oroszország ${ }^{* * *}$ & 18422 & $25,7 \%$ & - & 7050 & $51,5 \%$ & $+59,8 \%$ & $+67,9 \%$ \\
\hline USA & 104037 & $59,7 \%$ & $43,8 \%$ & 3679 & $13,5 \%$ & $+38,1 \%$ & $+57,9 \%$ \\
\hline
\end{tabular}

"Közép- és Kelet-Európa = Azerbajdzsán, Bulgária, Csehország, Észtország, Kazahsztán, Kirgizisztán, Lengyelország, Lettország, Litvánia, Magyarország, Oroszország, Örményország, Románia, Szlovákia, Ukrajna.

"EAE = Egyesült Arab Emírségek.

*** Oroszország esetében az Európába történő utazások régión belüli (short haul) utazásnak számítanak.

\section{Forrás: MTÜ (2017)}

A tengerentúli turisták egyik közlekedési eszköze könnyebb igénybevehetősége miatt hagyományosan a vasút, amely a jövő nyertese is lehet. Az elmúlt évtizedekben először a fapados repülés, majd az autóbuszos távolsági közlekedés jelentett jelentős kihívást a vasút

\footnotetext{
${ }^{1}$ Valentyin P. Katajev: A kör négyszögesítése / Kvadratura kruga (1928)
} 
számára, úgy tủnik azonban, hogy új piaci egyensúly alakul ki, megváltozott fogyasztói igényekre válaszolva.

A világban egyre erősödő környezettudatosság előretörését a vasúttársaságok ki akarják használni, a trend egyértelmü: a tudatos fogyasztók a környezetbarát közlekedést helyezik elötérbe. Egy ausztrál, európai vonatjegyeket is árusító utazási iroda munkatársai szerint az ügyfelek között egyre inkább előtérbe kerülnek a tudatosan választó ügyfelek (SUTHERLAND 2019). Tanulmányunk másik kutatási kérdése a vasúti közlekedés lehetőségei ebben a megváltozott helyzetben. Vizsgálatunk és az abból levont következtetések, valamint az azok alapján tett javaslataink célja, hogy a vasúti közlekedés versenyképessége és közlekedési munkamegosztásban betöltött szerepe tovább növekedjék, így segítve környezetünk megóvását.

Cikkünkben a városlátogató turisták és a vasúti járattervezés új megközelítésén át vizsgáljuk a turizmus és a vasút viszonyát: a már eddig is jól müködő közép-európai vasúti körutazások „négyszögét”: a Budapest - Prága - Bécs - Zágráb útvonalat elemezve teszünk javaslatot új, Budapestről induló vasúti körutakra, csillagtúrákra, bemutatva, hogy mely vasúti desztinációkban érdemes Budapestet kiinduló állomásként hirdetni. A bemutatott példák alapján reményeink szerint a föváros és az ország turisztikai bevételei növelhetök.

\section{Városlátogató turisták}

A városok a kultúra széles skáláját kínálják, a szabadidős termékek és szolgáltatások szerteágazó kínálatát nyújtják (LÖRINCZ - MICHALKÓ 2011). Általában kimondható, hogy az európai városokba más földrészekröl érkező turisták zöme maga is városlakó, azaz rendelkezik tapasztalatokkal arról, hogyan kell a várost fogyasztani. Ez egyben rámutat a városok globalizációjára is (McDonaldisation) (LŐRINCZ - MICHALKÓ 2011).

A városba látogatók motivációi akár többrétegűek is lehetnek. A hivatás- vagy egészségügyi turisták például szabadidejükben hódolhatnak a kulturális szenvedélyüknek, gyönyörködhetnek a látnivalókban, kulináris élményeket szerezhetnek. A távolról érkező városlátogatók leginkább adott város (multi)kulturális élményeit keresik. A természeti és építészeti örökség megtekintése mellett további kulturális jellegü élmények befogadására vágynak. Éppen ezért a legnagyobb turistaforgalmú városok nem az egy kiemelt vonzerővel rendelkező települések, sokkal inkább azok, amelyek regionális központok és rengeteg kultúra (kulturális hatás) keveredése jellemző rájuk (például Berlin).

Fontos kiemelni, hogy a városlátogató turizmus nem tekinthető szezonális tevékenységnek, a városok vonzereje egész évben megvan, leginkább az egyes korosztályok szabadságolási rendje (szünideje) hat rá. Ugyanakkor ma már a városlátogató turizmus népszerübb, mint a tengerparti üdülés (TO 2018). Ez is óriási segítség a hatékony és egyben ezért környezetkímélő közlekedés szervezésénél.

A hosszabb tartózkodások helyett a 2-3 éjszakás tartózkodások a jellemzőek, az utazások átlagos időtartama csökken (RAFFAY 2020). Éppen ezért a tengerentúli utasok a 2-3 hetes európai szabadságuk alatt több várost is felkeresnek. E tekintetben lényeges kérdés lehet a városlátogatások közti holtidő, azaz az utazás ideje. Egy adott térség vonzerejét növelheti, ha a látnivalók között kevés holtidővel tud mozogni a turista.

Vannak olyan turisták, akik egy adott városban kevesebb, mint 1 napot töltenek el (hiperturisták), kérdés azonban, hogy ők mennyi élményt tudnak befogadni. Számukra a gyorsaság fontos tényezö, így a közlekedés terén is a legyorsabb eszközt választják. A többség azonban az élmények befogadására szán elegendő időt, így számukra nem feltétlenül a 
gyorsaság a legfontosabb, sőt egyes trendek igyekeznek a turizmust szándékosan le is lassítani (slow-tourism). Az élmények befogadásának egyik módja lehet az utazás alatti gondolkodás, az élmények feldolgozása, a pihenés; sőt, maga az utazás is lehet élmény. Az ilyen típusú turisták számára lehet ideális közlekedési eszköz a vonat, mely megfelelően gyors, ugyanakkor hagy időt a relaxációra és a vonatos utazás is lehet élmény. Mindezek mellett a környezettudatos turista-viselkedés is a vasút irányába terelheti a látogatókat. A felelős közlekedési eszközválasztásról a következő fejezetben szólunk.

A különböző vasúti közlekedési megoldások eltérő jellegüek. A nagysebességü vonalak általában olyan vonalvezetésüek, hogy kevés látnivalót kínálnak, sok az alagút és a zajvédő fal, elmosódnak a közeli tárgyak a száguldástól. A hagyományos, 19. századi építésủ hegyi vasutak viszont maguk is turisztikai érdekességek lehetnek. E két szélsőség közötti mező igen széles. A Dunakanyar vasútja például fontos elővárosi és nemzetközi fővonal, egyszerre nyújt kilátást a folyamra és a környező hegyekre, csodálható meg a visegrádi vár, és egyben utazási lehetőség is Prága és Budapest között. Sok utazó, ha választhat, a lassabb, de szebb útvonalat járja be és kerüli a nagysebességü közlekedést.

\section{Környezettudatos közlekedési eszközválasztás}

A repülés ma már a mindennapi közlekedés része. A közlekedő repülőjáratok az $\mathrm{ICAO}^{2}$ adatai szerint a világ széndioxid kibocsátásának $2 \%$-áért felelősek (ICAO é. n.), mely kibocsátás nagymértékben hozzájárul a globális felmelegedéshez. Kutatók megállapították, hogy a fapados légitársaságok elöretörésével a rövid távú repülés társadalmilag elfogadott napi szintű utazási móddá vált (GÖSSLING et al. 2019). Ez Magyarországon is tapasztalható volt olyan széles körben ismert jelenségek kíséretében, mint például a külföldi, föleg brit fiatalok Budapesten megtartott legénybúcsúi. A mindennapi repülés elterjedése okán a légi utasok száma az elmúlt években évi 3,7 milliárd föt ért el, míg az összes közlekedési mód együttvéve 7,1 milliárd utast szállított el (MARKHAM et al. 2018). Látható, hogy az utasok több mint fele repülővel utazott. Ez a légiközlekedési ágazat jelentős növekedését hozta a 2010-es években. Kérdésként merül fel, hogy az emberek miért utaznak ilyen jelentős számban repülővel. Egy 2009 évi angol kutatás (HARES et al. 2010) szerint ennek okai az alábbiak:

- a repülés az utazás egyetlen megfelelő opciója;

- nem tudatosul a klímaváltozás iránti személyes felelősség;

- a szabadságot nagyra értékelik.

A Bevezetésben említett ausztrál példa az európai kontinensen is megtalálható. A 2010-es évek közepétől az ismert, fiatal svéd klímaaktvista Greta Thunberg által indított „Péntekek a jövőért"3 mozgalom tagjai már szándékosan nem utaznak repülővel, hanem a környezetkímélőbb vonattal és hajóval. A mozgalom jelszava a „Flygskam” (repülésszégyen) elöször 2016-ban jelent meg a közösségi médiában, míg angol változata a „flightshame” 2018ban (BECKEN et al. 2019). A szó által megtestesített magatartásforma azóta egyre több emberhez jut el. Lényege, hogy az ember szégyent érez az okozott környezetszennyezés miatt, ha a repülést választja.

A közösségi médiafelületeket kihasználva a mozgalom és ezáltal a tudatos közlekedési módválasztás egyre népszerúbb. A környezetvédelem további világszerte ismert arcai, például David Attenborough természetfilmjei vagy Ferenc pápa Laudato si’ kezdetű enciklikája szintén

\footnotetext{
${ }^{2}$ International Civil Aviation Organization - Nemzetközi Polgári Repülési Szervezet

${ }^{3}$ Fridays For Future (FFF)
} 
hatalmas közönséghez jutnak el. A klímaváltozással kapcsolatos téma aktualitása megkérdőjelezhetetlen és egyértelmüen kirajzolódnak a fejlett országokban követett fejlödési irányvonalak. Az európai politikai térben a fenntarthatóság kérdésköre kiemelt területté vált: az Európai Bizottság elnöke ezt tette politikája központi fogalmává (PORTFOLIO 2019).

E társadalmi viselkedésváltozás eljutott tehát egy olyan szintre, amikor az utasok azért utaznak adott közlekedési móddal, hogy védjék a környezetet. GONDA és RAFFAY kutatása szerint hazánkban az emberek 37,8 \%-a jár el így (GONDA - RAFFAY 2021). Ennek leginkább a vasúti közlekedés felel meg, így a tudatos eszközválasztás a vonatok nagyobb arányú igénybevétele felé mutat. Amennyiben az ember környezettudatosan él, szabadságát, vakációját is ennek megfelelöen tervezi meg és turistaként is így viselkedik. Tanulmányunkban a következőkben a vasúti közlekedés turisztikai aspektusait vizsgáljuk, annak érdekében, hogy választ kapjunk a Bevezetésben felvetett kutatási kérdésekre.

\section{A vasúti járattervezés turisztikai alapú megközelítése}

A vasúti járattervezés hagyományos módja szerint a vasúttársaságok leginkább az egymásnak nyújtott teljesítmények kiegyenlítésére törekedtek (például futott kocsikm), így az egyes nemzetközi járatok nem minden esetben a tényleges utasigényeket követték elégítették ki. A járattervezés ${ }^{4}$ turisztikai alapú megközelítése azonban megfelelően tud reagálni a tényleges utazási igényekre. MICHALKÓ (2007) könyvében a turizmus infrastruktúrájának tekinti a közlekedési ágazatot, amelynek mennyiségi és minőségi mutatói kiemelt jelentőséggel bírnak a vendégforgalom eredményes lebonyolításában. Megítélése szerint a vasúti személyszállítás európai színvonalú infrastrukturális elemeit képezik azok a járatok, amelyek nemzetközi és belföldi viszonylatban fövárosok, régió- és megyeközpontok gyors, kényelmes megközelítését teszik lehetővé (MICHALKÓ 2007).

Az európai vasúti hálózat sürüsége lehetővé teszi, hogy a főbb turisztikai célpontok elérhetők legyenek vasúton is. A vágányok behálózzák az egész kontinenst, még a brit vagy dán szigetekre is közvetlen eljutást biztosítanak. Összehasonlítva a vasúti ellátottságot a polgári repülöterek számával, teljesen egyértelmü, hogy vasúttal sokkal több település és turisztikai célpont közelíthető meg, mint repülővel. Természetesen a repülés esetében is felmerülhet az egyéni és a közösségi közlekedés kombinációja (autóbérlés a repülőtéren), sőt a GDS ${ }^{5}$ rendszerek kialakításának egyik fó mozgatórugója pont ez volt, hogy a kevesebb számú repülőtérről több célpont is kényelmesen elérhető legyen.

Amikor döntünk, hogy utazásunkat miként bonyolítsuk le, akkor a közlekedés minőségi paramétereit vesszük számításba. Ezek a következők:

- kényelem;

- ár;

- gyorsaság;

- rendelkezésre állás.

A vasúti turizmus keresletét elemezve SOMOGYI B. (2019) doktori értekezésében az utasok motivációját három csoportba sorolja. Fontos kérdés a választási preferencia és a motiváció összekapcsolódása. Mind az elsődleges motivációjú, csak a vasúti élményért utazók, mind a

\footnotetext{
${ }^{4}$ A fogalom a menetrendek kialakításán túl a vasúti közlekedési szolgáltatás egészének tervezését jelenti.

${ }^{5}$ Global Distribution System - Globális elosztó rendszer
} 
másodlagos és harmadlagos motivációjú, a vasutat közlekedési eszközként választók esetében (SOMOGYI 2019) a fenti minőségi paraméterek játszanak szerepet döntésük meghozatalakor.

A továbbiakban ezeket a paramétereket vizsgáljuk a vasút tekintetében.

A kényelem az utazási körülmények egyik legfőbb meghatározó tényezője. Egyéni közlekedés választása esetén ugyan kizárjuk idegenek társaságát, ugyanakkor a vezetés terhe még kerékpározás esetén is, ránk nehezedik. A közúti közlekedés jelentős stresszhelyzetet eredményez, ez mindenképpen megterhelö és pihenésünk ideje alatt nem biztos, hogy ezt választjuk.

A közösségi közlekedés esetén mint utasok veszünk részt a folyamatban, így a közlekedés menetét nem magunk irányítjuk. Az ilyen választás esetén bíznunk kell a szolgáltatóban, cserébe teljes kényelemben utazhatunk adott járattal. De mit is jelent ez? Sok körülmény játszhat ebben szerepet, kezdve a jármű ergonómiai kialakításától, az utastársakon át a nyújtott szolgáltatásokig. A vasút esetén az alábbi megoldások szolgálhatják az utasok kényelmét (LÉVAI - MOLNÁR 2020):

- termes és fülkés ülökocsik közlekedtetése (szeparáció);

- 1. osztályú utazás: kevesebb utas, nagyobb lábtér;

- étkezőkocsi: az utazás tartama alatt egyes vonatokon lehetőség nyílik a menet közbeni étkezésre, de az étkezőkocsiban lehetséges csak italfogyasztás is (például sör, kávé, üdítők, stb.);

- külön kijelölt ülöhelyek: családi szakasz, külön fülke nők és kisgyermekkel utazók részére, csendes szakasz;

- éjszakai utazás lehetősége: speciális, alvásra alkalmas kocsik közlekedtetése;

- kerékpárszállítás;

- $\quad$ segítséggel élők utazása;

- lazább csomagszabályok;

- fedélzeti szórakozás lehetőségei: asztal, WIFI csatlakozás, filmnézés, zene vagy rádióhallgatás, olvasáshoz, konnektor és USB töltő, külön olvasólámpa biztosítása.

Az ár kérdése szorosan összefügg a nyújtott szolgáltatásokkal. Az természetes, hogy a legtöbb turista próbál az utazáson spórolni és pénzét inkább a célpontokon elkölteni, ugyanakkor sokan vannak olyanok is, akik számára az utazás is élmény és ez idő alatt is szeretnének megfelelően magas szintű szolgáltatásokat igénybe venni. A kétféle attitüdöt az árazással is követni kell, a kisebb társaságok, családok részére speciális árszintek kialakításával lehet kedvet csinálni a vasúti utazásokhoz. Az éjszakai vonatokon az ágyban alvás lehetőségét is kínálják szolgáltatók, ennek természetesen felára is van.

A gyorsaság tekintetében a repülés vezető helye megkérdőjelezhetetlen, de már az 1960-as évektől kezdődően a vasúti szektor alapvető törekvése volt, hogy a vonatok sebességét olyan mértéküre emelje fel, amely már a repülővel történő kontinentális eljutás versenytársa lehet. Az első európai nagysebességü vonat Franciaországban1981-ben közlekedett Párizs és Lyon között, azóta számos vonalon indult el az emelt sebességü ( $>200 \mathrm{~km} / \mathrm{h}$ ) közlekedés. Ugyan a vonatok végsebessége még jócskán elmarad a repülés sebességétől, de az eljutási időket tekintve már a nagysebességü vasúti közlekedés felveszi a versenyt a rövid- és közép távú kontinentális légiközlekedéssel. 
A vonatok többsége azonban a 100-200 km/h sebességtartományban közlekedik, így ez a paraméter még mindig a légi közlekedés felé billenti a mérleg nyelvét, és az alacsonyabb tartománnyal még a személygépkocsik is versenyre kelnek. Ugyanakkor az is igaz, hogy azok számára, akiknek az utazás is élményként jelenik meg, nem biztos, hogy szükségük van az emelt sebességre. Ahogy már említettük, a hegyekben, vízpartokon közlekedő vonatokból elénk táruló táj szépségét csak „megfelelően lassú” tempó mellett lehet élvezni.

A rendelkezésre állás tekintetében a vasutat csak a közösségi közlekedés többi módjával érdemes összehasonlítani. Ennél a paraméternél első számú a menetrend jelentősége, amely szolgáltatási katalógusként is értelmezhető. A menetrendet ugyanis nem pusztán egy út-idő grafikonként kell értelmezni, hanem mindannak megjelenítöjeként, amit adott vonattal kapcsolatban egy vasúttársaság, mint szolgáltatást kínál, amelynek csak egyik eleme a vonat közlekedésnek időrendje. A rendelkezésre állásnál azonban csak ez az időrend fontos, persze ez is tágabb értelemben. Ebbe beleértjük azt is, hogy a vonat mely napokon közlekedik. Ez azért fontos, hogy tudjuk, a tervezett napon egyáltalán elérhető-e a szolgáltatás vagy sem. Nem minden nap közlekedő vonatok esetében kérdésként merül fel, hogy tudunk-e alkalmazkodni a közlekedési rendhez és a vonat közlekedési napján utazni, vagy más közlekedési eszköz után kell néznünk.

Azon célpontok között, ahol rendszeres és nagy forgalom realizálódik naponta több vonat is közlekedik célszerü az ütemes menetrend alkalmazása. Ebben a menetrendi szerkezetben a vonatok (LÉVAI - MOLNÁR 2020):

- az órának mindig ugyanabban a percében;

- ugyanabban az irányban;

- ugyanarról a vágányról, peronról;

- ugyanolyan minőségü és kinézésű szerelvénnyel közlekednek és

- ugyanolyan átszállási, csatlakozási lehetőségeket biztosítanak.

Az ütemes menetrend az utasok számára (LÉVAI - MOLNÁR 2020):

- könnyen megjegyezhető menetrendet;

- egyértelmü utastájékoztatást;

- könnyü (intermodális) csatlakozás-szervezést biztosít.

Ezek az előnyök egyre inkább elterjedtté teszik az ütemes menetrendi szerkezetet, így a nemzetközi vonatoknak is ehhez kell alkalmazkodniuk adott országban. Ez bizonyos esetekben problémát jelenthet, amennyiben a szomszédos országok által használt menetrendi szerkezetek eltérőek. Az ütemes menetrend jellemzőjeként ismert szimmetriatengely (BORZA et al. 2007) megfelelő megválasztásával ezek a problémák kiküszöbölhetők.

A nemzetközi vasúti járatok tervezésekor már a fentiekre tekintettel kell a vonatok útvonalát és szolgáltatásait kialakítani. Ezt az újfajta, turisztikai alapú megközelítést szükséges alkalmazni annak érdekében, hogy a vasúti szektor versenyképessége megmaradjon. Emellett figyelemmel kell lenni a 2. pontban részletezett környezettudatos módválasztásból következő utazási igényekre. E két kihívásra adható válasz az ütemes menetrend alapján kialakított, megfelelően magas színvonalú vasúti szolgáltatás, lehetőleg közvetlen eljutási lehetőségekkel. Amennyiben adott városok között ütemes menetrendi szerkezetet alakítunk ki, az az egész napi eljutási lehetőség biztosításával megfelelően tudja biztosítani a vasúti körutazások lebonyolíthatóságát. 


\section{A közép-európai vasúti körutazás négyszöge}

Közép-Európa turisztikai szempontból három legjelentősebb városa Bécs, Budapest és Prága. Negyedik, ötödik és további helyszín is vizsgálható, jelen tanulmányban egy negyedik pontot rögzítettünk, ez Zágráb. A horvát fóváros nem hasonlítható a másik három városhoz, inkább az Adria kapujaként, turisztikai elosztó központként került e körbe. A következő pontokban az említett városok közötti kapcsolatokat vizsgáljuk, illetve választ keresünk az utasforgalom nagyságára.

\subsection{Vasúti kapcsolatok}

A négy város elhelyezkedését az 1. ábra szemlélteti. A 2021-es menetrendi évben elérhető nemzetközi vasúti összeköttetéseket ${ }^{6}$ piros és kék vonalak jelölik. Amennyiben a négy várost körbe szeretnénk látogatni, akkor a következő közvetlen vonatok közül választhatunk:

- Budapest - Prága;

- Budapest - Bécs;

- Bécs - Prága;

- Bécs - Zágráb;

- Budapest - Zágráb.

\section{1. ábra. Közép-Európa legfontosabb városainak elhelyezkedése.}

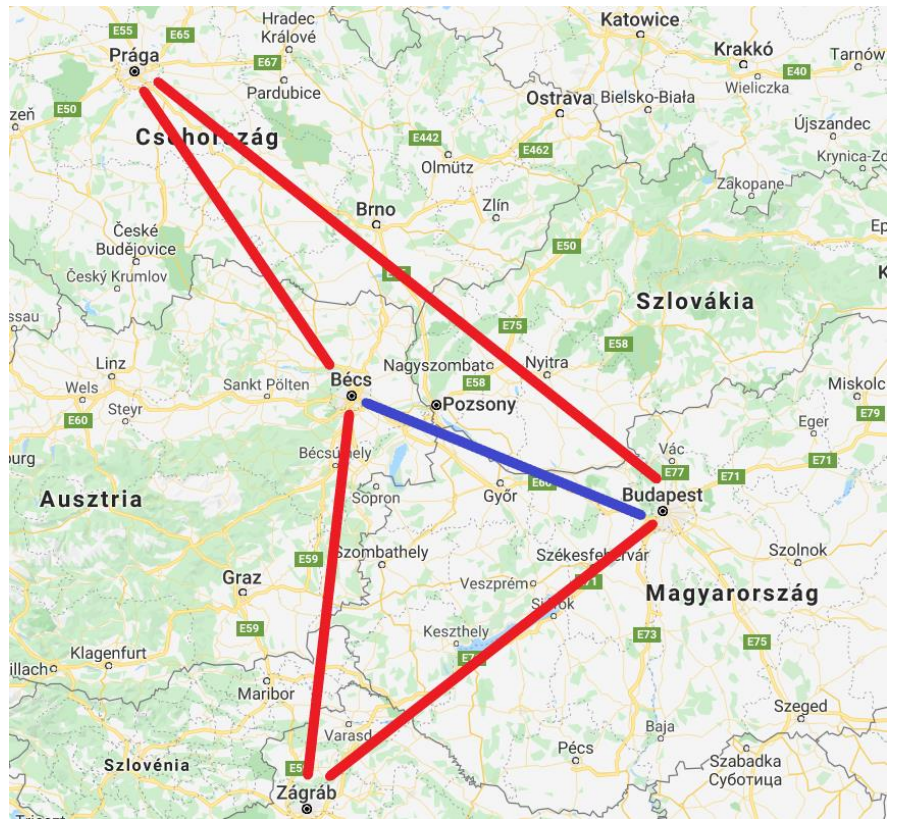

Forrás: google.com/maps alapján saját szerkesztés

Látható, hogy csak Prága és Zágráb között nincs közvetlen vonat, a többi relációban elérhető a közvetlen összeköttetés. A forgalomra a járatok számából következtetünk. Azt feltételezzük, hogy a kínálat a kereslet változását követve bővül. A közlekedő vonatok nagy számából arra következtetünk, hogy a legnagyobb utasforgalom a Budapest - Bécs, Budapest - Prága és Bécs - Prága várospárok között zajlik. Mivel a piacon verseny van, így a pontos utasforgalmi adatokat több szolgáltatótól lehetne összegyüjteni, de azok üzleti titoknak minősülnek, így nem

\footnotetext{
${ }^{6}$ Eltekintve a pandémia alatti korlátozásoktól.
} 
hozzáférhetők. Az utasforgalom nagyságának növekedésére a közlekedtetett vonatok darabszámának emelkedéséböl következtetünk (2. és 3. táblázatok).

2. táblázat. Vonatpárok száma Budapest és Bécs között, naponta.

\begin{tabular}{|c|c|c|c|c|}
\hline év & 2006 & 2011 & 2016 & 2021 \\
\hline vonatpár $(\mathrm{db})$ & 7 & 10 & 12 & 18 \\
\hline
\end{tabular}

Forrás: vasúti menetrendek alapján saját szerkesztés

3. táblázat. Vonatpárok száma Budapest és Prága között, naponta.

\begin{tabular}{|c|c|c|c|c|}
\hline év & 2006 & 2011 & 2016 & 2021 \\
\hline vonatpár $(\mathrm{db})$ & 4 & 4 & 5 & 7 \\
\hline
\end{tabular}

Forrás: vasúti menetrendek alapján saját szerkesztés

A nemzetközi idegenforgalom szempontjából a legfontosabb a Budapest - Bécs viszonylat. A két város között óránként felváltva közlekednek railjet és EuroCity (EC) márkanevü vonatok. A térségben magántulajdonú szolgáltató is jelen van az állami cégek mellett (Student Agency), kisebb járatszámmal. Az elmúlt 15 évben a vasúti forgalom az osztrák és a magyar főváros között dinamikusan bővült. A naponta közlekedő vonatok száma több, mint kétszeresére nőtt.

Forgalomnagyságot tekintve a következő, alacsonyabb forgalmú relációk a Bécs - Prága, Budapest-Prága viszonylat. A vonatok kétóránként közlekednek, valamint a magyar és a cseh főváros között rendelkezésre áll éjszakai összeköttetés is. Budapest felől Prágába a vonatok Pozsonyon keresztül közlekednek, így a szlovák főváros a rendszer részét képezheti, ugyanakkor idegenforgalma nem mérhető a többi városhoz. Ezzel szemben utasforgalmi szempontból Pozsony kiemelt pont, csúcsidőszakokban a pozsonyi fóállomáson sokszor hosszú percekig tart a fel- és leszállás folyamata a vonatokról.

A legkisebb vasúti utasforgalom Budapest - Zágráb és Bécs - Zágráb között mérhető. Ennek megfelelően mind Bécsből, mind pedig Budapestről napi két vonatpár közlekedett. Sajnos az utóbbi időben a magyar - horvát forgalom visszaesett, így a második vonatpár közlekedését az érintett táraságok a nyári időszakra korlátozták. Prága és Zágráb közötti közvetlen fogalom elenyészö, így a két város között nem is közlekedik közvetlen vonat. Zágráb tehát kilóg ebböl a rendszerből, de jellemző mozgás a térségben, hogy a városok felfedezése után a turisták az Adria part felé folytatják az utat.

Az utasforgalom összetételéről elmondható, hogy a nem európai turisták nagy számban választják a vasutat az európai utazásaik eszközéül. A távol-keleti államokból és az amerikai kontinensről érkező utazók és kisebb-nagyobb csoportok tesznek európai körutakat és látogatják meg ezeket a városokat. Természetesen nem csak Európán kívüliek utaznak ezekben a viszonylatokban, távolabbi európai országokból érkező turisták is szívesen használják a vasutat és az egyes desztinációk között az adott országok állampolgárai is jelentős számban utaznak.

\subsection{Versenytársak}

A kutatás teljességéhez hozzátartozik a versenytársak, azaz az autóbuszok és a légi közlekedés helyzetének elemzése is.

\subsubsection{Autóbuszok}


A nemzetközi buszközlekedés egyre inkább felfutóban van az utóbbi időkben. Elsősorban köszönhetö ez annak, hogy Európa központi területén a belföldi piacnyitással új lendületet kapott a távolsági buszozás. A különböző elektronikus értékesítési csatornákon könnyen elérhető, alacsony árú jegyek révén elsődlegesen az árérzékeny csoportokat szólítják meg a buszos szolgáltatók. Több ernyőszervezet is létrejött, amely egységbe fogta a különböző szolgáltatókat és saját árpolitikát és egységes megjelenést alkalmazva könnyen elérhetővé tette a buszos szolgáltatásokat szerte a kontinensen. A piacvezető pozíciót végül a Flixbus vívta ki, térségünkben még a Regiojet márkanév is jelen van, számos, új szolgáltató pedig már kiszorult a piacról az utóbbi években.

A szolgáltatás keretében az alábbi jellemző járatszámok ismertek a városközi forgalomban:

- Budapest - Bécs között a „csúcson” félóránként jártak a buszok;

- Budapest - Prága között jellemzően órás-kétórás sürüséget értek el;

- Budapest - Zágráb között 2-3 óránkénti követés alakult ki;

- Bécs - Zágráb óránként-kétóránként indultak a járatok;

- Bécs - Prága óránként, félóránként közlekedtek;

- Prága - Zágráb napi néhány járat indult.

A folyamatosan változó járatszámokból az kivehető, hogy egyszerre növekvő és hullámzó a kereslet a buszközlekedésre a városok közötti forgalomban, a keresleti változásokat a szolgáltatók igyekeznek lekövetni, a menetrend sürün változik, miközben egymással is komoly (öldöklőnek is nevezhető) versenyben vannak. A buszos részarány növekedésének láthatóan vannak korlátai, az egyik szolgáltató (Student Agency) egyre inkább a vasúti összeköttetésekre koncentrál, a buszos piacról vonul vissza.

Ugyanakkor a buszjáratok egyes szolgáltatási elemei a fizikai kialakítás kötöttségei (a tér szükössége) miatt elmaradnak a vasúti szolgáltatások jellemzőitől, így a kényelmi szempontok a potenciális utasok szemében a vasút javára döntik el a választást. Nyugat-Európában az autóbusz inkább csak az árérzékeny fogyasztói csoportok számára jelent megoldást, hiszen a legtöbb esetben a vasútnál (és természetesen az egyéni autós, motoros eljutásnál) lassabb. Kelet-Közép-Európában, egyes viszonylatokon a busz gyorsabb tud lenni a vasútnál, ezért akár dominánssá is válhat közösségi közlekedési eszközként egyes viszonylatokon. A vizsgált térségben Zágráb kedvező autópályás kapcsolatai és elavult vasúti infrastruktúrája miatt inkább buszos személyszállítási célpont. Az autóbuszos szolgáltatók törekednek arra, hogy a vasútnál alacsonyabb árakkal dolgozzanak. Ez Nyugat-Európában jellemző szegmentáló tényező, Közép-Európában azonban a vasúti árak alacsonyabbak, a közút és a vasút között valódi árverseny van.

\subsubsection{Repülés}

A térségben a repülés egyedül a Prága - Budapest, illetve Prága - Bécs útvonalakon kap szerepet. A többnyire fapados légi járatokkal az eljutási idő városközponttól városközpontig számítva is órákkal rövidebb a vasúti menetidőnél, így ebben az esetben az erős verseny addig folytatódik, amíg nagysebességü pályák rendelkezésre nem állnak ezen a vasútvonalon. Ugyanakkor a közvetlen járatok száma alacsony (napi 1-2), így ez nem sok utas számára jelent kedvezö megoldást. A vasút elönye az egész napos rendelkezésre állás, így az utasok a nap folyamán bármikor útra kelhetnek.

\subsection{3. Árverseny}


$\mathrm{Az}$ árverseny azonban erős, így az egyes szolgáltatók árai nem térnek el lényegesen. Az alábbiakban a Budapest - Prága viszonylaton mutatjuk ezt be. A piacon legrégebb óta jelenlévő szolgáltató, az állami vasúttársaság árai alá mennek a piacra belépők. Ugyanakkor a nyomott árszint miatt az árak szórása a szárazföldi közlekedésben alacsony.

4. táblázat. Legolcsóbb jegyárak euróban megadva a Budapest - Prága viszonylatra, 2021. szeptember 17-i vásárlással, adott napra.

\begin{tabular}{|c|c|c|c|c|}
\hline utazás napja & Ryanair & Regiojet & MÁV-START & Flixbus \\
\hline 2021. október 1. & 34 & 18,3 & 20 & 18,6 \\
\hline 2021. október 2. & 13,4 & 18,3 & 20 & 18 \\
\hline
\end{tabular}

Forrás: szolgáltatók weboldala alapján saját szerkesztés

( $1 €=350$ forint árfolyamon számítva)

\section{Fejlesztési lehetőségek}

Budapest idegenforgalma szempontjából a térség másik két súlyponti központjával kiépített közlekedési kapcsolat létfontosságú. A város hálózati szerepe egyben turisztikai szerepének egyik fontos tényezője. Jelenleg a lassú közlekedési kapcsolatok miatt a térség felfedezése a szükre szabott szabadságukat Európában töltő tengerentúli utasok számára kevésbé hatékony. Természetesen itt az élményeket habzsoló, sok várost bejáró turisták és a lassabb, komótosan felfedező utazók elvárásai eltérőek. Prága esetében éjszakai összeköttetés is rendelkezésre áll, így egy szállodai éjszakát kiváltva tudnak az utasok eljutni a két város között. A nagy távolságról érkező utazók ezeket az éjszakai eljutásokat is keresik, az éjszakai utazás időhatékonyságát kihasználják. A fejlesztési lehetőségek tehát kétfélék:

a) a hagyományos logika szerinti fejlesztések az ár-érték javítását árcsökkentéssel vagy minőség emeléssel célozzák (gyorsabb, kényelmesebb vonatok);

b) a szálláshelykiváltó utazási lehetőségek fejlesztése esetében a pihenési idő számít, nem a menetidő, ezért olykor az éjszakai vonatok lassabban is közlekednek, az árak összehasonlítása esetében pedig a szálláshely költségigényét is figyelembe veszik.

Az első lehetőség az infrastruktúra fejlesztésével, illetve a szolgáltatási színvonal emelésével érhető el. A tervezett nagysebességü vasúti kapcsolatok kialakítása után München, Varsó és Kolozsvár is bekapcsolódhat a közép-európai vasúti körbe, így ezen városok turistaforgalma ezáltal is erősödhet. A második eset az éjszakai vonalhálózat fejlesztésével valósítható meg.

\section{1. Új útvonalak}

A vasúti útvonalak hálózatának fejlesztése Budapest központ szerepét erösítheti. A már bemutatott „négyszög” mellett olyan egyéb körutazások kapcsolhatók a budapesti repülös érkezési és indulási ponthoz, amelyek egymástól néhány órányi vonatozásra találhatóak. Ezek az útvonalak akkor jöhetnek létre, ha ezekben a térségekben a vasúti infrastruktúra megújul. Egyes szakaszokon a korszerüsítés már megkezdődött. Elemezve a vasúti infrastruktúra nyújtotta lehetőségeket, az alábbi javaslatokat tesszük a Budapestről indítható további vasúti körutazási lehetőségekre:

- „Balkáni hangulat”: Budapest - Ljubljana - Zágráb - Belgrád - Budapest (2. ábra);

- „Erdély kincsei”: Budapest - Kolozsvár - Segesvár - Brassó - Budapest (3. ábra); 
- „Kárpátok kulturális kavalkádja”: Budapest - Munkács - Lemberg - Kassa - Budapest (4. ábra).

\section{2. ábra. „Balkáni hangulat” körutazás}

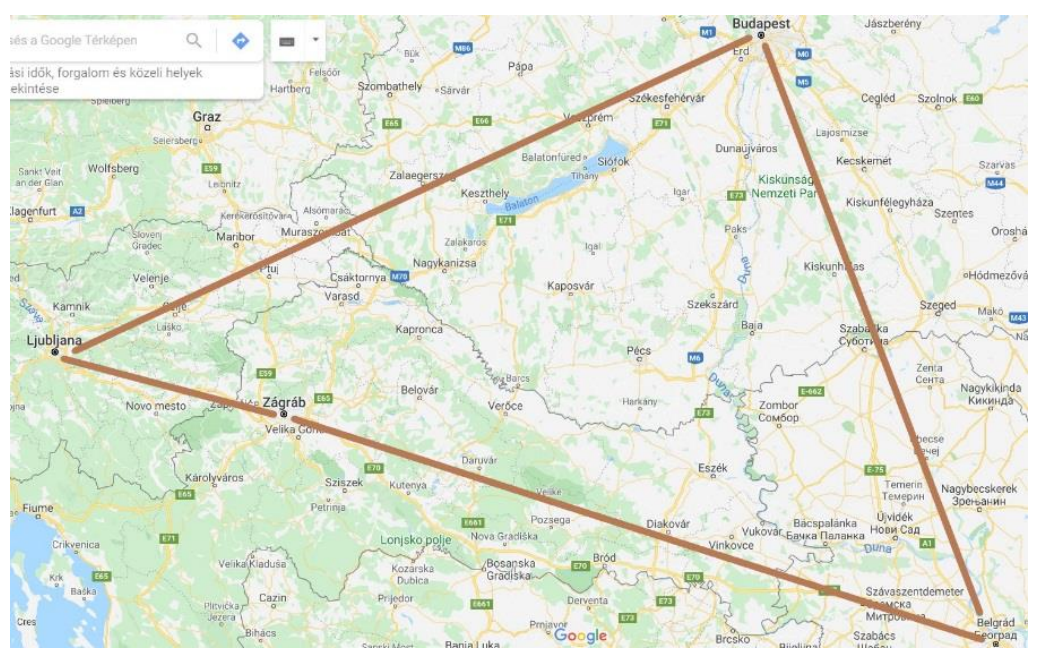

Forrás: google.com/maps alapján saját szerkesztés

\section{3. ábra. „Erdély kincsei” körutazás}

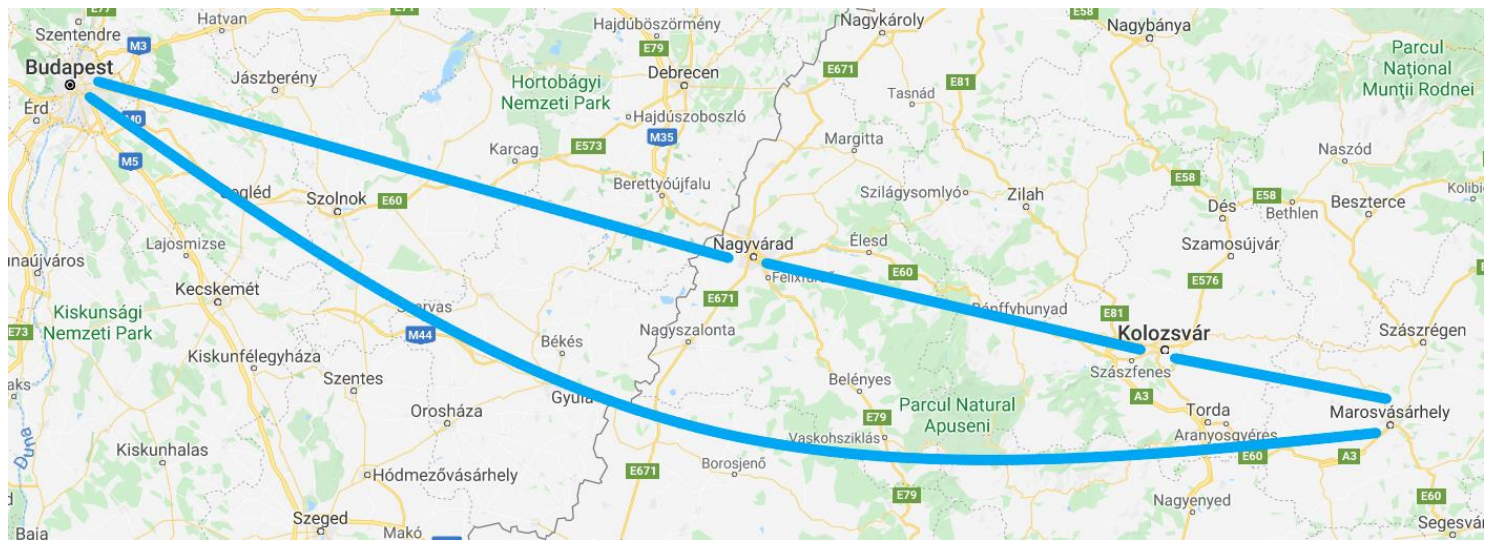

Forrás: google.com/map alapján saját szerkesztés

\section{4. ábra. „Kárpátok kulturális kavalkádja” körutazás}

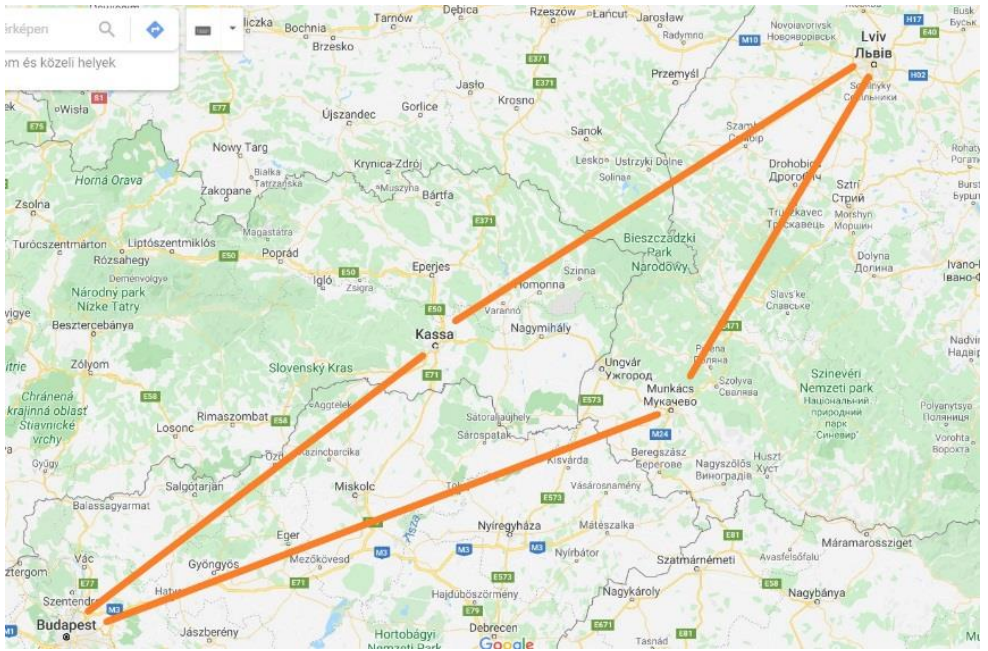

Forrás: google.com/maps alapján saját szerkesztés 
A körutazások mellett a másik gyakori utazási mód, egy célpont kiválasztása, és onnan különböző másik célpontok felkeresése csillagtúra szerüen, azaz minden esetben visszatérni a központi városba. Ezek alapján megfontolásra javasoljuk a következő, Budapestről induló vasúti célállomásokat városlátogatásokra, egy napra (5. ábra):

- Pozsony;

- Brno;

- Kassa;

- Nagyvárad;

- Arad;

- Temesvár;

- Szabadka;

- Újvidék;

- Eszék;

- Varasd;

- Graz.

\section{5. ábra. Vasúti csillagtúrák Budapestről}

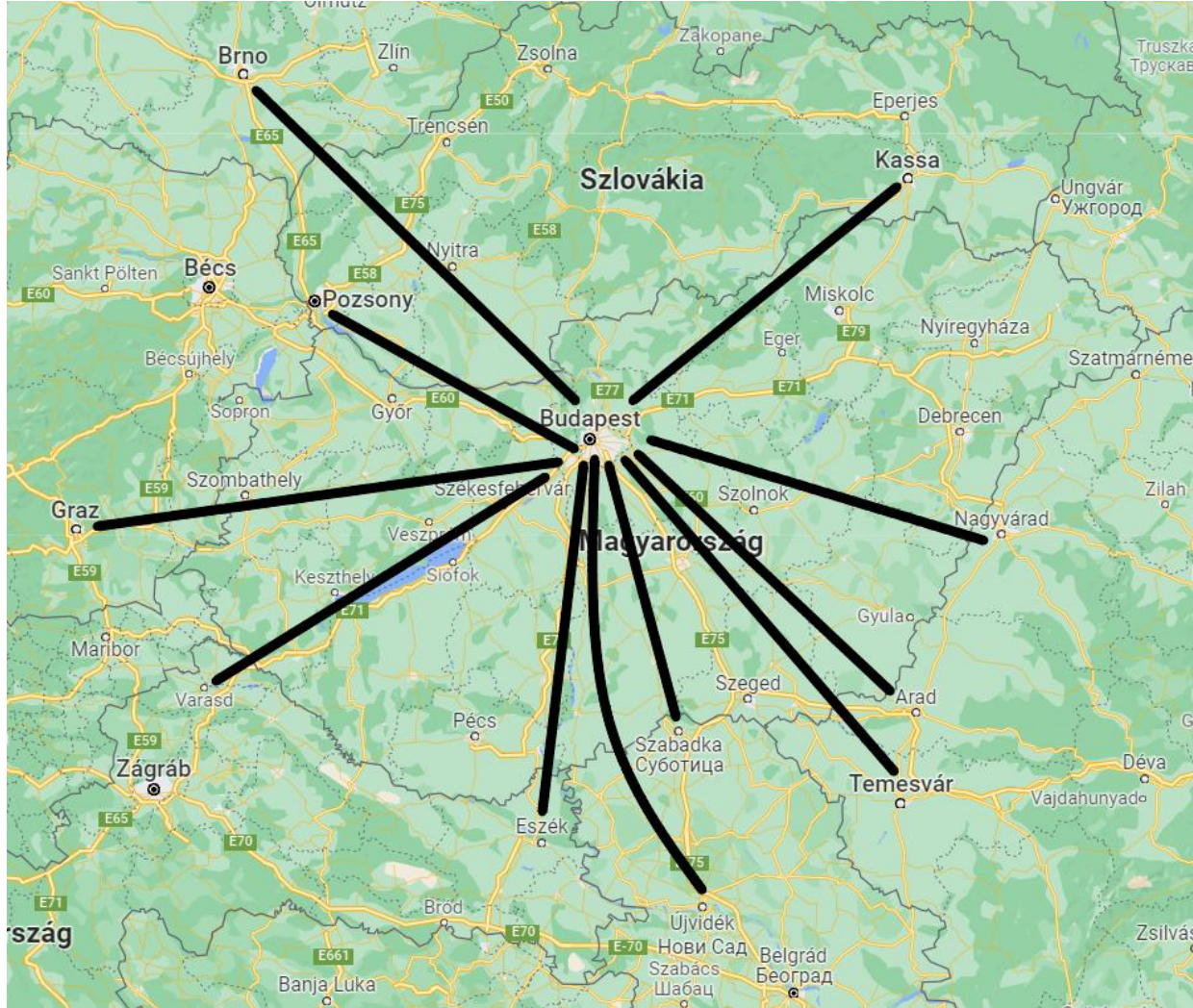

Forrás: google.com/maps alapján saját szerkesztés 
Érdemes kiemelni továbbá két olyan desztinációt, melyek kulturális értékei és nemzetközi turistaforgalma jelentősek, ugyanakkor Budapestről már nem tehetők meg a vasúti utazások oda-vissza egy nap alatt. Ebben az esetben javasoljuk éjszakai vonatok közlekedtetését, így az utazás és a szállás egyszerre letudható, a városok felfedezésére az egész nap rendelkezésre áll. Az egyik ilyen célpont Krakkó, a másik Szarajevó és Mostar (6. ábra).

\section{6. ábra. Budapest - Krakkó, Budapest - Szarajevó - Mostar}
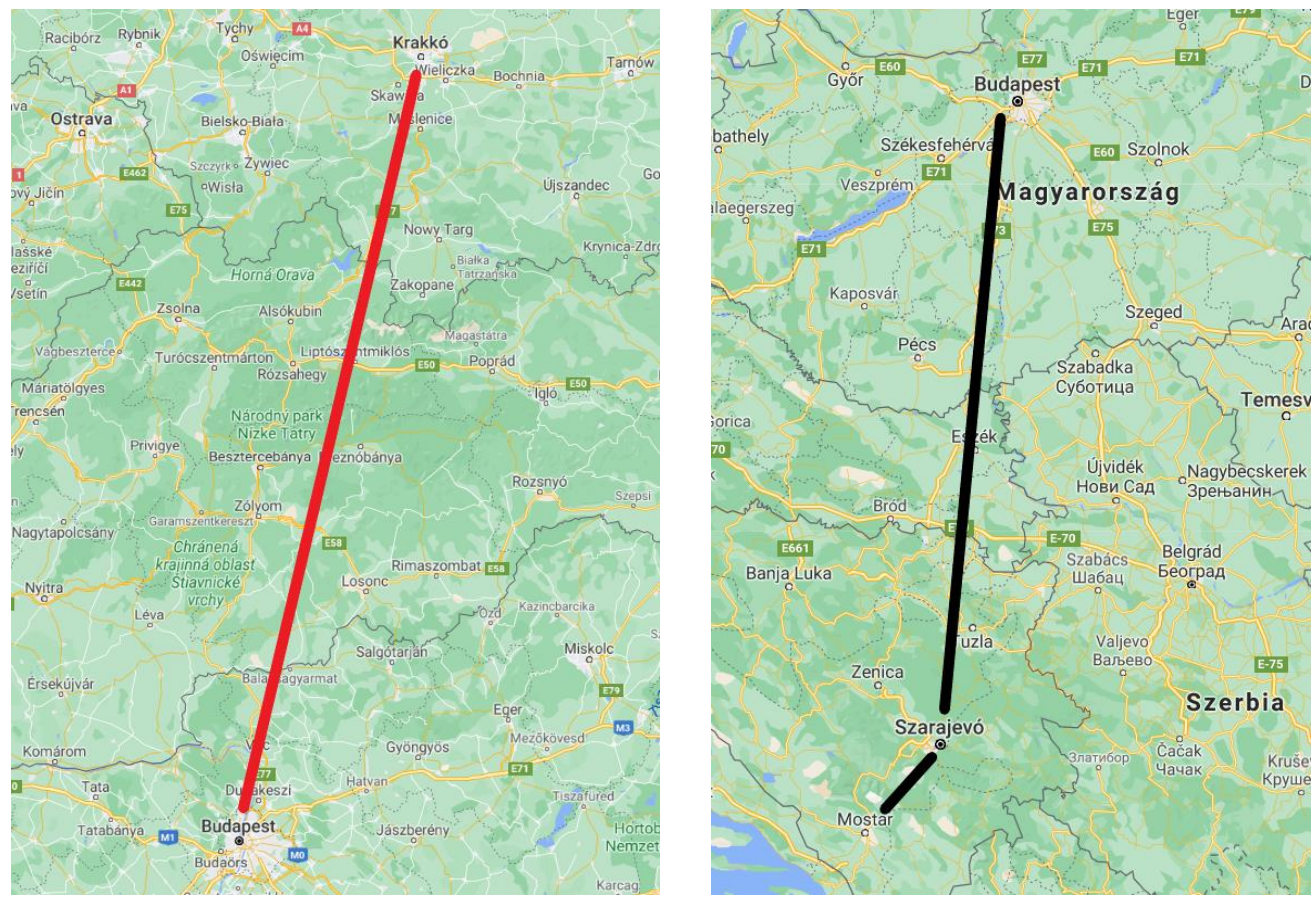

Forrás: google.com/maps alapján saját szerkesztés

\subsection{Járattervezés}

Az új útvonalakon már közlekednek vonatok, egyes városokba közvetlen eljutási lehetőség is adódik Budapestről, ugyanakkor a bemutatott turizmus alapú járattervezés a következő fejlesztéseket igényli:

- a körutazások városai közötti közvetlen vonatok indítását (vasúttársaságok együttmüködését);

- a csillagtúrák célpontjai és Budapest között egész napos, ütemes menetrend és közvetlen vonatok bevezetését olyan módon, hogy a célvárosban legalább 5-6 óra látogatási idő rendelkezésre álljon;

- szükség esetén a nappali vonatokat kiegészítését éjszakai szolgáltatással;

- a légkondicionált kocsik közlekedtetését;

- fedélzeti szolgáltatások nyújtását (étkezőkocsi, többcélú-teres kocsi ${ }^{7}$, WIFI, stb.);

- a nemzetközi és a belföldi viszonylatok összefüzését (közszolgáltató vonatok továbbközlekedése a határon túlra);

- az ilyen vonatok finanszírozási rendszerének megoldását (OSZTER 2019).

\footnotetext{
${ }^{7}$ kerékpárszállítás, mozgáskorlátozottak utazási lehetősége, gyerekmozi, stb.
} 


\section{Következtetések}

A COVID járvány bezárta a világot az emberek elött. A kifejlesztett ellenszerek hatása remélhetőleg hamarosan érvényesül, és a világ újra kinyílik. Feltételezésünk szerint a részleges vagy teljes nyitás új lendületet adhat a turizmus számára. Szakértői meglátások szerint a turizmus lökésszerü növekedést érhet el, ez pedig szükségessé teszi a rendelkezésre álló közlekedési kapacitások vizsgálatát. Sok tengerentúli és ázsiai turista gondolhatja úgy, hogy európai körutazást tervez és egy szabadság alatt több európai célpontot is felkeres. Az ilyen, általában városlátogató turisták számára lehet vonzó az európai városok viszonylag könnyü és gyors egymás utáni elérése.

Cikkünk ebböl a feltételezésböl kiindulva vizsgálta a közép-európai térséget, ahol a nagy történelmi városok kedvező lehetőséget teremtenek a körutazásokra. Kutatási hipotéziseinket e szerint fogalmaztuk meg, keresve a választ a vasúti turizmus új lehetőségeire. A kelet-középeurópai térség turizmusának szempontjából Budapest lehet az egyik központ, ahonnan különféle vasúti körutazások és csillagtúrák indíthatók. Ahhoz, hogy a magyar főváros ezt a szerepet betölthesse, szükséges a vasúti járattervezés turisztikai alapú kialakítása. Cikkünkben bemutattuk ennek alapjait és javaslatot tettünk azokra a járattervezési fejlesztésekre, melyekkel kutatási céljainkat elérhetőnek gondoljuk. A tanulmányban konkrét javaslatokat tettünk a vasúti körutazásokra és csillagtúrákra.

Vizsgálataink alapján tanulmányunk főbb megállapításai az alábbiak:

- az élményeket habzsoló, időhatékony és slow utazók utazási preferenciái is eltérnek, ezért a vasúti infrastruktúra- és szolgáltatásfejlesztéseknek mindkét csoportot célozniuk kell;

- Budapest nemzetközi idegenforgalmi szerepét a közlekedési hálózat kapcsolatai jelentősen erősítik, a vasúti fejlesztések folytatása szükséges;

- a vasúti infrastruktúra kiépítettsége alapján Budapest alkalmas a kelet-közép-európai térség vasúti turisztikai központ szerepének betöltésére akár körutazások, akár csillatúrák esetén;

- a vasúti járattervezés hagyományos módszerei mellett alkalmazni kell a turizmus alapú megközelítést is;

- a járattervezés során fejleszteni kell a menetrendi kínálatot és a vasúti szolgáltatási színvonalat.

Megállapításaink fö mondanivalója az, hogy a vasúti fejlesztések a turisztikai szektor, illetve a környezettudatosság szempontjából is kiemelt jelentőségűek. Javaslataink a turisztikai szakemberek számára lehetnek hasznosak azáltal, hogy felhívják a figyelmet Budapest lehetséges új turisztikai szerepére, mint a távolról érkező turisták közép-európai körutazásának vasúttal történő lebonyolításának bázisvárosa. A vasúti szakemberek számára pedig bemutattuk, hogy a nemzetközi vasúti járattervezés ma már nem müködhet csak hagyományos, kölcsönösségi alapon, hanem szükséges új módszerek bevezetése is. Ugyanakkor javasoljuk a kutatások kiterjesztését a hazai turisztikai központokra és városokra is.

A cikkben kifejtett fejlesztési javaslatok mindezek mellett tovább növelhetik a vasúti közlekedés versenyképességét, valamint fokozhatják a szektor térnyerését a környezetbarát közlekedési módok között. Ezzel elérhetőnek látjuk azt a célt, hogy bolygónk megmentése érdekében szükséges lépéseket tennünk. 
Hisszük, hogy mind a vasúti közlekedésnek, mind pedig a turisztikának van jövője, egymásra találásuk esetén pedig, akárcsak Katajev színmüvében, kifejezetten kedvező eredmények érhetők el mindkét szolgáltatási piacon, így az együttmüködés már szinte szükségszerünek tűnik. Az együttmüködés kialakításával egyben a cikk címét adó „matematikai problémát” is meg tudjuk oldani.

\section{Köszönetnyilvánítás}

Jelen publikáció az Innovációs és Technológiai Minisztérium Kooperatív Doktori Program Doktori Hallgatói Ösztöndíj Programjának a Nemzeti Kutatási, Fejlesztési és Innovációs

Alapból finanszírozott szakmai támogatásával készült.

\section{Irodalomjegyzék}

BECKEN, S. - FRIEDL, H. - STANTIC, B. - CONNOLLY, R. M. - CHEN, J. (2020): Climate crisis and flying: social media analysis traces the rise of „flightshame”. Journal of Sustainable Tourism, https://doi.org/10.1080/09669582.2020.1851699

BORZA, V. - ISTVÁN, Gy. - KORMÁNYOS, L. - VINCZE, B. (2007): Integrált ütemes menetrend I. rész. Közlekedéstudományi Szemle, 57(11), pp. 402-416.

CSAPÓ, J. - TÖRÖCSIK, M. (2020): A turizmus jövője, a nemzetközi és hazai turizmus legújabb trendjeinek elemzése elméleti és gyakorlati megközelitésben. Pécsi Tudományegyetem KTK, Pécs.

GONDA, T. - RAFFAY, Z. (2021): Környezettudatosak-e a hazai turisták? Turizmus Bulletin, 21(2), pp. 4-14. https://doi.org/10.14267/TURBULL.2021v21n2.1

GÖSSLING, S. - HANNA, P. - HIGHAM, J. - COHEN, S. - HOPKINS, D. (2019): Can we fly less? Evaluating the „necessity” of air travel. Journal of Air Transport Management, Vol. 81. https://doi.org/10.1016/j.jairtraman.2019.101722

HARES, A. - DICKINSON, J. - WILKES, K. (2010): Climate change and the air travel decisions of UK tourists. Journal of Transport Geography, Vol. 18, Issue 3, pp. 466-473. https://doi.org/10.1016/j.jtrangeo.2009.06.018

ICAO (é. n.): Aircraft Engine emissions. https://www.icao.int/environmentalprotection/pages/aircraft-engine-emissions.aspx (letöltve: 2021. 01. 30.)

LÉVAI, ZS. - MOLNÁR, B. (2020): Vasút és turizmus: lehetséges válaszok a globális klímaváltozás kihívásaira. In: Albert Tóth A. - Happ É. - Printz-Makó E. - Kupi M. - Török N. (szerk.): Multidiszciplinaritás a turizmusban - X. Nemzetközi Turizmus Konferencia Tanulmánykötet, Széchenyi István Egyetem, Győr, pp. 81-98.

LŐRINCZ, K. - MICHALKÓ, G. (2011): A városi turizmus. In: Michalkó G. (szerk.): Turisztikai terméktervezés és fejlesztés. PTE. http://www.eturizmus.pte.hu/szakmaianyagok/Turisztikai\%20term\%C3\%A9ktervez\%C3\%A9s\%20\%C3\%A9s\%20fejleszt\%C3\%A 9s/book.html (letöltve: 2021. 01. 31.)

MARKHAM, F. - YOUNG, M. - REIS, A. - HIGHAM, J. (2018): Does carbon pricing reduce air travel? Evidence from the Australian 'Clean Energy Future' policy, July 2012 to June 2014. 
Journal of Transport Geography, Vol. 70. pp. 206-214. https://doi.org/10.1016/j.jtrangeo.2018.06.008

MICHALKÓ, G. (2007): Magyarország modern turizmusföldrajza. Dialóg Campus Kiadó, Budapest-Pécs.

OSZTER, V. (2019): How to establish and operate cross-border public transport in a peripheral rural area? The example of the Central and Southern section of the border between Austria and Hungary. Prace Komisji Geografii Komunikacji PTG, 22(1), pp. 52-65. https://doi.org/10.4467/2543859XPKG.19.006.10926

RAFFAY, Z. (2020): A COVID-19 járvány hatása a turisták fogyasztói magatartásának változására. Pécsi Tudományegyetem, KTK. https://ktk.pte.hu/sites/ktk.pte.hu/files/images/008_A\%20COVID$19 \% 20$ jarvany $\% 20$ hatasa $\% 20 \mathrm{a} \% 20$ turistak $\% 20$ fogyasztoi $\% 20$ magatartasanak $\% 20$ valtozasara .pdf

SOMOGYI, B. (2019): A magyarországi vasúthálózat turizmusföldrajzi térszerkezetben betöltött szerepe, valamint a vasúti turizmus potenciális fejlesztési lehetöségei Magyarországon. PhD értekezés, Pécsi Tudományegyetem, Földtudományok Doktori Iskola, Pécs.

SUTHERLAND, C. (2019): Forget flying: Why tourists can't get enough of train travel. Escape. https://www.escape.com.au/news/forget-flying-why-tourists-cant-get-enough-oftrain-travel/news-story/665bd38888a558245ead167352866c0e (letöltve: 2021. 01. 29.)

\section{Egyéb források:}

MAGYAR TURISZTIKAI ÜGYNÖKSÉG (2017): Európai turizmus 2017-ben - Trendek és kilátások.

PORTFOLIO (2019): Íme az európai növekedési stratégia a nagy klímavédelmi átálláshoz. https://www.portfolio.hu/unios-forrasok/20191217/ime-az-europai-novekedesi-strategia-anagy-klimavedelmi-atallashoz-410559 (letöltve: 2021. 03. 21.)

TURIZMUS ONLIE (2018): Már népszerübb a városlátogatás mint a tengerparti üdülés. http://turizmusonline.hu/friss/cikk/mar_nepszerubb_a_varoslatogatas_mint_a_tengerparti_udu les (letöltve: 2021. 09. 14.) 